\title{
Geen Grenzen Meer: An American Musical's Unlimited Border Crossingi
}

\author{
Laura MacDonald and Myrte Halman
}

Since its 2003 Broadway debut, Wicked's international audiences have embraced productions of the musical in a variety of countries. Wicked has thus conquered the world with its ideological framework of American values, as much as with its story of friendship between two young women. In transcending national borders, Wicked becomes a transnational commodity. We interview Dutch actress Willemijn Verkaik, who discusses her multiple, multilingual and transnational performances as Elphaba in Wicked, and analyse Dutch-American relations and the Netherlands' lasting role as cultural middleman, suggesting that Verkaik's multinational Elphabas, constructed through a Dutch filter, make her a cultural diplomat, one consistent with the Netherlands' larger role since the Pilgrims migrated there prior to crossing the Atlantic. The pilgrimages made by the actress, as well as by her international fan base, offer insight into Wicked's powerful position in constructing identities and communities that may no longer be bound by borders.

After the Dutch actress Willemijn Verkaik's final performance as the green witch Elphaba, in the Dutch production of the musical Wicked, the show's producer, Joop van den Ende, acknowledged her earlier German residency as Elphaba in Stuttgart and 
Oberhausen. In his speech from the stage of the Circustheater in Scheveningen he said:

"What I loved about your performance tonight was your ability to so freely express your emotions, and give your own interpretation of this role in your native language. I hope you can be similarly free in your performance in American." ${ }^{\text {"ii }}$ Van den Ende's slip of the tongue, describing Verkaik's Broadway debut in American, rather than in English, is telling. He seemed to emphasize the Americanness of her New York performances, despite her Dutch nationality. This raises the question of whether her previous German and Dutch language performances were also performances of Germanness and Dutchness. Stacy Wolf discusses Wicked's Act 1 finale, when Elphaba flies by broomstick for the first time and sings about "Defying Gravity:" "As she levitates to twenty feet above the stage floor, and most crucially, belts a loud and long 'me,' Elphaba tells the audience that this show is hers." ${ }^{\text {iii }}$ But what happens when Verkaik, as Elphaba, claims the show as hers, in German, Dutch and English?

Although Verkaik is not the first foreign performer to take over the lead in an American musical on Broadway, ${ }^{\text {iv }}$ her performances of Elphaba in four countries are more complicated than the journeys of the actress alone. In her first foray as Elphaba in Germany in 2007, Verkaik constructed a version of an American character outside America. She then played a Dutch Elphaba at home in the Netherlands from 2011-2013, before returning the character to Wicked's home, on Broadway, in February 2013. In November 2013, she debuted her Elphaba in the West End production of Wicked. Verkaik's international performances thus provide an exceptional and rich snapshot of musical theatre's complicated transnational circulation. With this kind of musical theatre 
cultural diplomacy, Verkaik is not unlike a diplomat, carrying out the Netherlands' role as a middleman in cultural diplomacy. This dates back to the Pilgrims' initial journey to the Netherlands, from where the potential of the New World first beckoned. A consideration of Dutch-American relations is therefore a crucial part of this article. The world-leading Dutch musical theatre production company, Stage Entertainment, also functions as a middleman in transnational musical theatre.

Based on Gregory Maguire's novel about the unlikely friendship of the witches of Oz, Wicked was adapted in 2003 as a musical by writer Winnie Holzman and composer Stephen Schwartz. In the musical we meet Glinda, who functions as a role model for spectators as she matures from giddy school girl to political leader. We also meet Elphaba, a young, talented, green-skinned witch, who ultimately becomes the Wicked Witch of the West. Having celebrated its tenth anniversary, Wicked continues to run on Broadway at the Gershwin theatre, where it has played more than 4000 performances and is the $11^{\text {th }}$ longest-running musical in Broadway history. ${ }^{\mathrm{v}}$ Its success and popularity are not limited to Broadway and the United States; Wicked may be the most widely circulated global musical theatre hit of the $21^{\text {st }}$ century. Audiences have embraced productions of Wicked in Australia, New Zealand, Korea, Japan, the Philippines, the United Kingdom, Germany, Finland, Denmark, the Netherlands and Mexico. A Brazilian production is in development for a 2015 opening.

Wicked has thus conquered the world, and in transcending national borders, we argue, Wicked becomes a transnational commodity. A consideration of Wicked's sites of performance will begin to establish the stickiness of transnational musical theatre 
circulation, whereby both spectator and spectacle are affected by their encounter. In her seminal study, Theatre Audiences: A Theory of Production and Reception, Susan Bennett acknowledges this interplay: "Both texts and performances have shown a growing absorption with the relationship of their art to those who view it actively in the theatre."vi In probing Wicked's transnational circulation and reception, this article builds on Bennett's observations, to expand scholarly understanding of this active spectatorship. As researchers of transnational musical theatre, we have attended performances of Wicked in New York City, Washington DC, Toronto, London, Scheveningen, and Oberhausen, evaluating these international productions as well as live and online fan responses. Along with the live events and sites of performance, we analyse the range of translations and accents used in these productions.

Rather than becoming standardized McTheatre, in its global productions Wicked offers unique performances to spectators who simultaneously consume both its Americanness and a local authenticity. With her multiple, multi-lingual performances, the Dutch “middlewoman" Willemijn Verkaik helps to reveal the potential for original local experiences of a globally successful American megamusical. The posters outside the Gershwin Theatre in New York City quote reviews crediting Wicked with defining the American musical, but as Stacy Wolf points out, “Wicked's producers, not surprisingly, emphatically stress its universality, asserting that Elphaba's 'difference' stands in for all difference." ${ }^{\text {vii }}$ Recreated and re-shaped by its various sites of performance, Verkaik's Dutch filter, and spectators' active, transnational consumption of her range of Elphabas, Wicked has become a flexible, transnational commodity. 


\section{Dutch middlemen}

Many scholars of globalization have been concerned with a basic, singledirection circulation of ready-made American popular culture, and view its potential to homogenize culture as a threat to national identity. Dutch American Studies scholar Rob Kroes, however, identifies "freedom and voluntarism involved in processes of cultural

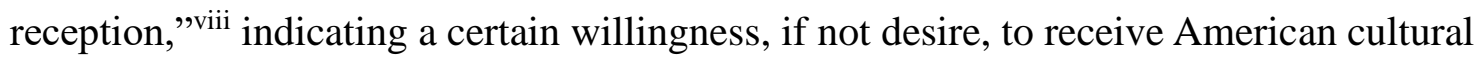
influences. Memories of World War II and the German occupation, along with a fear of economic dependence on Germany, contributed to a general turn by the Dutch towards the culture of the English-speaking world. While the Dutch were critical of American foreign policy throughout the Vietnam War, many "felt a deep solidarity with the opposition movements within the USA," Nico Wilterdink notes, “and were positively oriented to cultural achievements which were connected to or could be associated with these movements." ${ }^{\text {ix }}$ The Netherlands' relationship with the United States might be characterized as a love-hate one, as criticisms of the American 'system' were accompanied by imitation of American styles and fashion. American films, dance forms, fashion and advertising have been important carriers of alternative lifestyles in the Netherlands, and have been incorporated in Dutch society to such an extent that they are hardly perceived as 'American' anymore.

The widespread use of English in the Netherlands is seen not as an American influence, but rather as a part of a process of internationalization. Wilterdink describes the Dutch openness to foreign cultures as "peculiar," but with their internationalism, "they are in a unique position to play the role of international cultural middlemen...and 
combine foreign influences with indigenous elements to create a composite culture which is uniquely their own." middleman, through the theatre ownership and production of the Dutch corporation, Stage Entertainment. Willemijn Verkaik, the actress, further establishes this middleman role with her multiple international performances in Wicked. This casting of the Dutch as cultural middleman originated with the Pilgrims' escape to the Netherlands as they fled religious persecution in England. The Pilgrims, or Separatists, stayed in the United Provinces from 1607-1620. However, as William Bradford describes in Of Plymouth Plantation, the Netherlands eventually proved too religiously tolerant for the Pilgrims. ${ }^{\mathrm{xi}}$ During their years in the Netherlands they would have learned a great deal about the New World. Despite the Netherlands' relative inactivity in the Atlantic world with regard to colonization, the Dutch were by 1570 superior in printing and "at the center of the cartographic trade, and this meant that maps and atlases conveyed still further images of the Atlantic." "xii Here the Netherlands thus functioned as a cultural middleman, a role it would also assume in the New Netherlands colony in North America.

The Dutch colony depended on border crossers like Isaac Allerton who sailed on board the Mayflower with the Pilgrims from the Netherlands to Plymouth Rock. Although Allerton was of English origin, he differed greatly from Bradford and the other Separatists. Allerton valued learning the Dutch language, learning about other cultures, and set up extensive trade networks:

During Allerton's life in North America, which spanned most of the period of Dutch control of New Netherland, the colonies were filled with other people who used the 
same strategies. [...]Moreover, with one of the most heterogeneous populations, New Netherlands provided a haven for such people whose cross-cultural skills were crucial for its relationships with other colonies and with Native-Americans. ${ }^{\text {iii }}$

This is not to say that the Netherlands has a colonial history marked by acts of tolerance alone. Dutch practices in the Dutch East Indies illustrate in particular the darker side of Dutch colonial rule, marked in this region by a strict social and racial class system. However, in the New World, the Dutch thrived with their tolerance of other colonists and especially of Native Americans. People like Isaac Allerton based themselves in New Netherlands, ultimately acting as agents of this cosmopolitan colony. Because many American ideologies stem from these first Pilgrims, who, as demonstrated, were influenced by Dutch knowledge of and perspectives on the New World, analysing Dutch-American relations not only helps explain American ideologies in the $21^{\text {st }}$ century, but also establishes that the unique contemporary roles played by a Dutch actress and a Dutch production company are not random but rather the latest developments in a centuries-old trend.

\section{Transnational change for good?}

Stage Entertainment's latest venture is Rocky, a new musical based on the American film, and created by an American team of songwriters Lynn Ahrens and Stephen Flaherty, book writer Thomas Meehan, and director Alex Timbers. Translated into German, the musical premiered in Hamburg in 2012 prior to a 2014 Broadway opening. David Savran debates Rocky's Americanness and Germanness to conclude that this particular musical is "a symptom of the increased portability of transnational 
musicals. " ${ }^{\text {xiv }}$ As a transnational corporation, Stage Entertainment facilitates theatre spectators' active consumption of American popular culture, circulating images of the United States and American ideology not unlike the $16^{\text {th }}$ century circulation of images of America by Dutch cartographers. Its productions, enjoying critical and popular success before, and often without, opening in London or New York, are evidence of the "newly deterritorialized Broadway" Savran identifies. ${ }^{\text {xv }}$ Stage Entertainment is among “a generation of producers, writers, and directors who have absorbed the musical's conventions and vernaculars and who disseminate locally-produced, U.S.-style musical entertainments." ${ }^{x v i}$ But as will be shortly discussed, Wicked is a glocal product, modified by its performers and audiences in each performance site. Indeed, the production invites this, as director Joe Mantello explains. "What we try to do is instil this sense of ownership to every company, that it's not a replication but that there's a form there which is there to provide a kind of a structure for them but within that we really want it to be infused with their own personalities, their own sense of humor."xvii

This seems to oppose Joanne Tompkins and Dan Rebellato's readings of globally circulating musical theatre. Tompkins suggests, "Theatrical phenomena such as The Lion King almost preclude the performance of any representation of the 'local' in favour of a global theatrical language: international uniformity rather than cultural specificity is the point."xviii Rebellato concurs, proposing that "these shows appear almost entirely unchanged wherever they are," and that "the workers have little or no control over their conditions of work; all the creative decisions were taken years ago and are locked down." ${ }^{\text {xix }}$ If globally circulating megamusicals like Wicked are uniform and unchanged 
from their Broadway premieres, as Tompkins and Rebellato argue, why then do fans of the musical compile clips of the musical's different stars to compare their performances? If the workers have no input into creative decisions, how could spectators discern any differences between their performances? Fans' choices to compare performances of the vocal riff on the lyric "Fiyero" are telling, because the character's name remains consistent despite translation, providing a clear basis for comparison regardless of the given performer's language of performance. ${ }^{\mathrm{xx}}$ Further, were the actors in Wicked offering such uniform performances, what would prompt features such as Time Out New York's profile of all the women who have starred as Elphaba on Broadway, including the Dutch Verkaik and British Kerry Ellis? If creative decisions began and ended with the original Elphaba, Idina Menzel, why bother spotlighting the work of her successors ${ }^{\text {xxi }}$ Finally, if "in McTheatre even the biggest star is replaceable," why would spectators travel from Sydney to New York, or Scotland to the Netherlands, to see specific stars in Wicked, when other performers, giving (according to Tompkins and Rebellato) uniform performances, were more easily, and affordably, accessible? Wicked has, instead, clearly had the impact Tompkins values in the global circulation of theatre:

Certainly any play that is performed in another cultural context is likely to yield differing interpretations, and part of the attraction of theatre is its potential for introducing audiences to the cultural specificity of other 'local' cultural contexts. This in turn provides significant opportunities to interpret (or re-interpret) one's own culture and its local context from a new perspective. ${ }^{\text {xii }}$

These opportunities might not just be reinterpretation, but potentially even the social action and empowerment Wicked's characters model and its productions encourage. 
Indeed, Wicked appears to be playing the role Rebellato envisions theatre playing in cosmopolitanism, whereby audiences' "identification with characters on stage - often kinds of people that we would not ordinarily encounter - perhaps prepares the way for such identifications outside the theatre."xxiii Rebellato goes on to value how "in a theatre audience we can have a very sharp sense of being both ourselves and part of a larger unity," an experience which it would be difficult for Wicked spectators not to have, given the musical's celebration of individualism, its global brand and active fan communities. .xiv $^{\text {xiv }}$

Wicked has shown greater engagement with the world outside the theatres in which it is performed than many other long-running, globally-circulating musicals. While it is not uncommon for theatre companies to raise funds for charities, Wicked goes a step further. In November 2013 the company of the London production of Wicked remained onstage following the curtain call and actress Savannah Stevenson, who had just played Glinda, solicited donations for the Ben Cohen Standup Foundation, an antibullying charity. ${ }^{\mathrm{xxv}}$ She explained how Wicked companies around the world support antibullying campaigns, and bucket-wielding ushers collected donations from spectators exiting the theatre. What distinguishes the efforts of Wicked's multiple companies is that the anti-bullying campaign is just one initiative within the musical's "For Good" programme, through which each production "spearheads and supports a range of causes born out of themes of the award-winning musical." ${ }^{x x v i}$ Through such local engagement, Wicked becomes more than a live event, and thereby demonstrates its alive-ness. This is just one of several ways in which Wicked counters critiques of globally successfully 
commercial musicals as standardized McTheatre with diminished liveness. ${ }^{\text {xxvii }}$ The audience's awareness of local potential for change, and of its productive relationship with the musical on stage, thus contributes to Wicked's appeal, and leads to the ultimate purchase of a ticket.

\section{Finding America in Wicked}

In its transnational travels, Wicked circulates American myths and ideologies, and rather than restricting $\mathrm{Oz}$, American myths and ideologies, actively received via global musical theatre stages, may frame the live theatre event as a launch for global spectators' ongoing relationships with American society and culture. In his discussion of one of musical theatre's most iconic heroes, Alberto Sandoval-Sanchez calls Don Quixote's vocalized resolve in Man of La Mancha uniquely American:

In its musical creed, mobilizes the ideology of the American Dream and its set of ideologemes that define the American way of life: "I am what I am," "The sky is the limit," "Be all you can be," "Liberty and justice for all," "There can be a better day," "The sun will come out tomorrow." These are all poetically transcoded in the musical into "To dream the impossible dream" and "To reach the unreachable star!", becoming an integral metaphorical translation of the American spirit of resilience and the American way of life in the collective consciousness. $^{\text {xxviii }}$

One might now add "Defy gravity" to Sandoval-Sanchez's list, all the more so for its work in translating the American way of life into a global collective consciousness.

Stacy Wolf identifies just what Wicked is mobilizing when she states: "The musical features an all-American tale in which the underdog is different and unique, 
triumphant to the audience if not in the musical's world, the land of Oz." ${ }^{\text {xxix }}$ Wicked 's Americanness has its roots in the sequel (though it predates Wicked's publication and performance) which is still seen as a significant part of American culture, The Wizard of Oz. In The Wonderful Wizard of Oz in American Popular Culture, Neil Earle compares the tale of the land of $\mathrm{Oz}$ with the myths of the American frontier and the City on a Hill. ${ }^{\mathrm{xx}}$ Such mythology claims a certain exceptional role for the United States as a chosen country, a world power, and role model. Although Wicked does not explicitly refer to these myths, it certainly builds on them. Elphaba's desire to pursue her dreams and be accepted establishes a parallel between the Emerald City and any big American city where people might go to live their dreams.

For Elphaba, the Emerald City offers opportunities to develop her skills, feel accepted and at home. Upon her arrival, this is expressed very clearly in the song "One Short Day," which not only celebrates greenness (and therefore Elphaba's difference), but also extols the virtues of the city, as Elphaba sings: "I think we've found the place where we belong! I wanna be in this hoi polloi. So I'll be back for good someday to make my life and make my way."xxxi Both immigrants moving to America, as well as for Americans migrating to urban centers, often experience similar feelings and expectations of (job) opportunities, skill development, and a sense of belonging. Elphaba also takes up the American myth of exceptionalism. This myth began with the separatists who sailed from the Netherlands to America on the Mayflower in 1620 and landed on Plymouth Rock. Conceiving of themselves as God's chosen people, the Pilgrims 
elevated their lifestyle as a model for the rest of the world to look up to and aspire, and American exceptionalism can be traced back to this narrative of superiority.

More generally, the term pilgrim has also referred to people embarking on a quest to find a place they can call their home, where they might live out their destiny. In American society, interpretations of the Pilgrims, and pilgrims, have both carried great weight. These labels are equally useful when reading Elphaba in Wicked. Elphaba may be viewed by audiences and Ozians as exceptional, in that she has great (magical) potential, a great deal of courage and fierce determination. Indeed, like the Pilgrims, in the song "Defying Gravity" she conceives of herself as a figure to be lauded:

Unlimited.

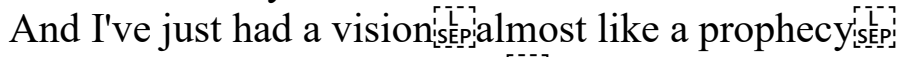

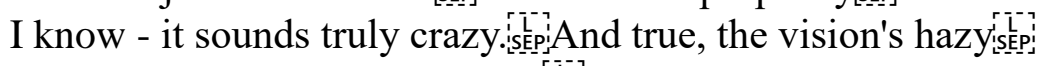
But I swear, someday there'll be

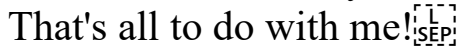

Later, while literally elevating herself by drawing on her magical powers, soaring above her persecutors and peers, Elphaba declares: "I think I'll try thépidefying gravity. And you can't pull me down!" Elphaba separates herself from society with this declaration, and act, of exceptionalism. She invites Glinda to follow her lead, and when Glinda declines, Elphaba reasserts her elevated position: "So if you care to find me sky...nobody in all of Oz, no wizard that there is or was: S'T-1

Though declaring her secession, as established earlier, Elphaba is also embarking on a pilgrimage to find herself, and a home. She makes a number of journeys throughout 
Wicked, first travelling to Shiz University. From there she travels to the Emerald City, before taking to her broomstick and travelling throughout $\mathrm{Oz}$ as an advocate for Talking Animals, before her ultimate pilgrimage takes her out of $\mathrm{Oz}$ forever. Elphaba can thus be linked to one of America's most beloved founding narratives, as well as to contemporary pilgrimages executed by people all over the world, hereby creating a sense of recognition for Americans and international spectators alike.

Though showcasing new world achievements and potential, analyses of Wicked can also problematize the myth of the American Dream, revealing the possibility of failed promises. "While opportunity abounds, so does the stress and tension that attends potential for loss or reemphasis," William W. Demastes writes in Interrogating America through Theatre and Performance. ${ }^{\mathrm{xxxii}}$ Considering Elphaba, the promise of acceptance initially proffered by the Emerald City eventually fails her miserably. Consequently, even if Elphaba eventually gets Fiyero, she loses everything else, including her best friend, who can never know she is still alive, and her sister. Additionally, she is forced to flee $\mathrm{Oz}$, the only place she was sure she belonged, and must abandon her dreams of working for the Wizard, living in hiding instead. In this sense then, Wicked portrays a problematic side of the American dream, as despite venturing to the Emerald City to escape a life of oppression, Elphaba must ultimately go into hiding or face constant danger, never fulfilling her political agenda or doing the good she aspired to accomplish. This failed promise of success, and the associated costs, inspired by the promised land, are not unfamiliar to contemporary pilgrims, whether immigrant or native-born American. 
Demastes considers the cult of the individual and builds on de Tocqueville to suggest "the dream of the individual actually works against the very goals that dream aims to retain in that the rare successes of individualism has inspired virtually a whole nation of aspirants whose odds of success guarantee majority disappointment." ${ }^{\text {"xxxiii } \mathrm{A}}$ pilgrim's, or Elphaba's, potential to fulfill an American dream is threatened not only by competition, but as demonstrated by the Wizard's dictatorship, "taboos that hedge in and constrain those on whom the normative structure loses its grip," limiting the Oz-asAmerica paradigm as a liminal space and reducing pilgrims' ability to formulate "a potentially unlimited series of alternative social arrangements." ${ }^{\text {xxxiv }}$ By offering the kind of model for change that Turner describes along with staging the hurdles and limitations he identifies, Wicked becomes even more valuable for its spectators. The transnational Elphaba Willemijn Verkaik sums up the musical's impact and influence as revealed by her stage door and social media conversations with fans: "In one sentence, 'If Elphaba can do it, I can do it too,' that's so great! And that's just me being on stage, telling a story. What more do you want? That people are walking away, out of the theatre with a smile and maybe even it helps them a little...That's me, but it's also the role, the character. A lot of Elphabas experience that and it's so rewarding, it's fantastic." ${ }^{\text {xxxv }}$ While Elphaba does not achieve all her goals, her strength and perseverance, and her "advocacy for the Talking Animals [make] her one of Broadway's most memorable agitators" (and thus a memorable model for potential social action). ${ }^{\mathrm{xx} x \mathrm{i}}$

As a musical, Wicked's Americanness is also confirmed by the promises its narrative presents. "The American Musical has been most consistently successful when 
its stories and themes resolve through the formation of conventional romantic relationships," Knapp posits, and while one conventional romantic relationship forms in Wicked, neither the conventional relationship nor two unconventional relationships fully succeed for the characters involved. ${ }^{\text {xxxvii }}$ Glinda and Fiyero meet at university and declare they are "perfect together." Later she manoeuvres their engagement but when his imperfections are revealed and he chooses Elphaba, Wicked's most conventional romance dissolves. Fiyero and Elphaba make up the musical's first unconventional romance, and while they are a couple by the musical's end, they must leave Oz forever, unable to celebrate their relationship with their friends and family as musical theatre couples typically do in finales. The second unconventional relationship Knapp refers to is the friendship between the two leading women. In Changed for Good: A Feminist History of the Broadway Musical, Stacy Wolf makes a queer reading and suggests that "the women form the musical's main romantic couple."xxxviii Wolf notes how the musical "signals that it will follow the conventions of mid-twentieth-century musical theatre, but queerly, with two women as the musical's couple."xxxix However, a queer reading of Wicked is complicated, most significantly by the fact that eventually, Elphaba runs away with Fiyero, choosing him, and not Glinda. The possibility of a queer reading is therefore also ultimately a failed promise. Lastly, Elphaba's sister Nessarose must also reconcile herself to the failure of the romance she constructs with the Munchkin Boq.

\section{Tribal Consumers and Transnational Performances}

Jill Dolan usefully identifies the potential in spectators attending a performance together, potential only multiplied by Wicked's multiple companies. “Audiences form temporary communities, sites of public discourse that, along with the intense 
experiences of utopian performatives, can model new investments in and interactions with variously constituted public spheres." ${ }^{\text {xl }}$ Building, as we have, on Victor Turner, Dolan notes how "the communitas they experience through utopian performatives might become a model for other social interactions." $x l i$ We have already suggested Wicked recruits spectators to agitate outside the theatre like Elphaba, but Dolan's concern with community and social interactions is also significant for the members of the spectating communities, which includes the temporary community in specific theatres, the imagined community of all Wicked spectators, and the communities sustained online via social media.

As a $21^{\text {st }}$ century megamusical, Wicked has benefitted from musical theatre consumers' and fans' engagement with the show via the internet and social media, a venue not available to earlier megamusicals circulating through the 1980s. In response to Willemijn Verkaik's performances in Wicked, an international community of fans have labelled themselves "Verkaikings," discussing her performances on social media fora as well as building sites to express their enthusiasm for her work. ${ }^{\text {xlii }}$ On the German Wicked Fan Forum, for example, plans were made to travel from Dortmund to Scheveningen just to see Verkaik again: "Is there anybody here who would go to Scheveningen with me for a day? That means driving there, seeing the show and going back? I would love to see Willemijn again."xliii Additionally, on the Willemijn Verkaik Fanpage on Facebook, Frouke Millet de St. Aubin posted that she would love a cd of Wicked sung by Willemijn, and does not care in which language. She even jokes about a possible Japanese edition, illustrating that Verkaik's multi-national, multi-lingual performances have not gone unnoticed, and that her skills are admired. ${ }^{\text {xliv }}$ In response to 
an announcement on the same fan page of a special concert by Willemijn Verkaik in the Netherlands, another fan remarked: "I need to go there. No matter how far."xlv

These comments illustrate fans' commitment to Willemijn Verkaik, and their appreciation of her multinational performances. "They sometimes tweet \#proudtobeaverkaiking," Verkaik explains, citing the Twitter hashtag used to link online comments. ${ }^{\text {xlvi }}$ While friendship as a result of fandom is valuable to the Verkaikings, as a tribe they illustrate how their consumption of Wicked as a commodity is extended beyond the live performance event. In Consumer Tribes, Cova, Kozinets and Shankar discuss consumption and participatory culture, observing:

Active and enthusiastic in their consumption, sometimes in the extreme, tribes produce a range of identities, practices, rituals, meanings, and even material culture itself. They re-script roles, twist meanings, and shout back to producers and other groups of people while they fashion their own differentiation strategies. They both absorb and resist the pre-packaged, off-the-shelf, brand-and-product meanings of marketers. ${ }^{\text {xlvii }}$

Wicked thereby becomes more than a night of entertainment for Verkaikings and other fans of the musical. Further, because this active consumption is occurring daily in multiple cities in multiple countries, Wicked prompts the development of multiple tribes, and thus an even wider range of associated identities, practices, rituals and meanings. Fan fiction and artwork are a major manifestation of tribal output, in which Glinda and Elphaba's story is extended beyond the musical, combined with other popular culture texts, and manipulated to create different relationships and plots than those imagined by Gregory Maguire, Stephen Schwartz and Winnie Holzman. 
The musical thus satisfies a range of different audiences' tastes, effectively being filled in and completed as multiple, foreign Wickeds. The musical acknowledges this to a certain degree via some of the souvenirs available in theatres where Wicked is performed. A keychain with the musical's title transposed on top of London's iconic skyline is available, as is a t-shirt with Elphaba's hat drawn as a map of England. Such local filtering helps make musicals like Wicked universal, according to Bruce Kirle: "Even the most popular of musicals is universal and timeless only in its willingness to adapt to the values, anxieties, and tensions of new audiences in new cultural moments." ^lviii Other productions also maintain newsletters keeping fans updated on ticket availability, casting changes and special events. In New York City, t-shirts branding the performance event "One Short Day in NYC" feature Elphaba with broomstick raised as the Statue of Liberty.

Beyond the basic translation of Wicked's songs and dialogue into foreign languages, the production itself, via its producers and performers, is prepared for glocal encounters. Bruce Kirle cites French director Michel Saint-Denis, who "argues that each country has a constantly changing historical personality. Since a theatre practitioner inevitably filters a text through his own country and his own time, works from other countries and other periods must be recreated in contemporary terms." ${ }^{\text {"xlix }}$ We are particularly interested in the notion of filtering American texts, like Wicked, through one's own country, what might be called a process of glocalization. During her run as Elphaba on Broadway in 2013, Willemijn Verkaik mentioned on Twitter that there is, "Nothing like a nice warm cup of coffee and a stroopwafel." In doing this, Verkaik offered an illustration of the kind of filtering this article is identifying. More than just a 
delicious snack from home, the stroopwafel Verkaik ate in New York City signified her Dutchness, and the persistence of her national identity through her performances in English, on Broadway. Though singing in “American” English, Verkaik does not become American. Her performance goes through a Dutch filter, a cultural negotiation as sticky as stroopwafel caramel.

On stage Verkaik thus sets down a performance of an American character, based on her own interpretation of Elphaba as a Dutch national. Following her debut as Elphaba in London, she noted, "I heard a few people at the stage door saying I'm bringing a different factor to the role and I think that's the Dutch... But what it is exactly, I'm not sure!"li She pointed out that given the small size of the Netherlands, "we tend to adjust very well to other cultures because people visit us all the time and we have to visit them, travelling for us is very normal to do. So yeah, I think I'm a world citizen, easily adjusting because I'm Dutch."lii Verkaik is not the only Dutch actress enjoying an international musical theatre career; Pia Douwes, Wietske van Tongeren, Michelle van den Ven and Annemieke van Dam have also found success singing in German and English beyond Dutch borders.

Along with this filtering and negotiation between a performer, her identity, character and site of performance, translation also plays a significant role as it can shift meanings. For example the Dutch translation of the song "Defying Gravity" seems to put particular emphasis on the idea of crossing and being unlimited by physical borders: "Nooit meer een grens aanvaarden, omdat die grens daar is."liii This literally translates as: Never accept a border anymore, just because that border is there. In English (on Broadway and in the West End), Elphaba sings lyrics which express a rather different 
meaning: "I'm through accepting limits, cause someone says they're so."liv Whereas the original English lyrics seem to refer to any barriers an individual might impose, the Dutch lyrics emphasize crossing actual land borders. The German translation of this same line also emphasizes man-made borders: "Mir setzt man keine Grenzen, Ich halt mich nicht daran,"lv which translated means: you cannot set limits for me, I won’t uphold them. These shifts in translation gain importance when the Dutch actress Willemijn Verkaik performs the same role in all three languages, literally crossing borders to do so, and fulfilling the tradition of Dutch middlemen. The announcement on the official UK Wicked website of her forthcoming West End debut as Elphaba demonstrated this by referring to her as the "previously announced international Wicked star Willemijn Verkaik." By classifying her as international, rather than Dutch, the site elided her Dutchness in favor of her international performances, thereby marking her as the middleman. The press release later labels Wicked "the global musical phenomenon," further drawing consumers' attention to the potential for an intercultural experience at London's Apollo Victoria theatre, should they purchase a ticket. ${ }^{\text {lvi }}$

Discussing her language fluency and the translations she has performed, Verkaik explains that, "if the translation goes in one particular direction, you go with it. I'm not sticking to the 'Unlimited' if the translation is 'Geen grenzen meer.' It never loses the message that Stephen Schwartz, Winnie Holzman want to get across. But yeah, during the song, it definitely will give me a few different approaches. And vocally also it's very different."lvii The consequences of language and performance location have resulted in different performances in the different productions she has appeared in. "I wouldn't say that they are four different Elphabas, but I think every time a new layer, maybe two 
layers are added to it," Verkaik explains. "Especially people who saw me everywhere could maybe confirm that, because of course there is always a basic Elphaba in me that's the basic one, but every city, every language, every accent, every experience gave me a new layer."|lviii Verkaik's performance requires the elimination of one accent and the performance of another, as she strives to achieve, for the audience, an accent-less experience. She admitted to be particularly satisfied with her work when "people in the audience especially don't have to think about where that person comes from."lix Verkaik's work with accents is not unlike the work of translators, those translating Wicked included, as translation scholar Lawrence Venuti explains, "The translator works to make his or her work 'invisible,' producing the illusory effect of transparency that simultaneously masks its status as an illusion: the translated text seems 'natural' i.e; not translated." $" 1 x$

Despite changes in lyrics and accents however, Verkaik also clearly states that the same ideas will still endure despite translation, as for example with the American ideologies Wicked's storyline carries. "What is really American about it? The passion to tell this kind of a story to people. It's very close to the heart, very honest, not afraid to show what you're passionate about, not afraid to shout that from the rooftops."'xi Verkaik's experiences thus demonstrate that translations and accents can be used as a tool of cultural negotiation by amending foreign productions of Wicked to the nation-assite-of-performance, but these productions nonetheless continue carrying the same Americanness of the essential Wicked. 
In Dutch, Elphaba sings, "Er zijn voor ons geen grenzen meer."1xii For us there are no longer any borders. This Elphaba seems to advocate for futures unlimited by any national borders. That Willemijn Verkaik has crossed multiple borders herself to star as Elphaba in several countries makes her performances even more rich and complex, and her example seems to offer an affirmative answer to Dennis Kennedy's question of whether "a spectator shifts cultural ground by watching interculturalism at work?"|xiii (132). Such interculturalism, activated by transnational musical theatre "does not represent a meeting of two cultures, but many, engaged in a complex network of dynamic exchange."xiv Within the network of cultures meeting in exchange through performances of Wicked (very likely shepherded there by a Dutch actress or a Dutch producer), American culture, though borderless thanks to Wicked, persists. As Verkaik has observed: "In America it's really like you know what, don't be afraid, just say how you feel. I think that's a very American thing and that's what Stephen Schwartz does [with Wicked]. And the funny thing is is that it works very well in different countries because they would have never said it themselves."lxv

i The authors would like to thank Tina Kosanke for her assistance with research in German and for the German translations which appear here. We are also grateful to Ruth Doughty, Deborah Shaw and Mark Thompson for their expertise and advice. We would also like to thank Willemijn Verkaik for her generosity in agreeing to be interviewed as part of this project. Finally, we are grateful to the two anonymous readers for their thoughtful and thorough responses.

ii 'Eindapplaus Allerlaatste Wicked En Speech Joop van Den Ende - 11 Januari 2013', YouTube video, 9:05, posted by 'Maikel Schram', 12 January 2013, http://www.youtube.com/watch?v=aX379w5AVNs\&feature=youtube_gdata_player, accessed 23 May 2014.

iii Stacy Wolf, Changed for Good: A Feminist History of the Broadway Musical (Oxford: Oxford University Press, 2011), p. 4. 
iv Foreign stars have been appearing in Broadway productions for many decades, most notably in the Festival of International Don Quixotes during Man of La Mancha's Broadway run, as well as more recently with exchanges between New York and London leading performers in musicals such as Les Miserables, Spamalot, and Chicago.

v Internet Broadway Database, http://www.ibdb.com/production.php?id=13485, accessed 23 May 2014.

vi Susan Bennett, Theatre Audiences: A Theory of Production and Reception (London: Routledge, 1997), p. 7.

vii Stacy Wolf, '“Defying Gravity": Queer Conventions in the Musical Wicked', Theatre Journal 60, 1 (March 2008), p. 11.

viii Rob Kroes, ed., Within the US Orbit: Small National Cultures Vis-a-Vis the United States (Amsterdam: VU University Press, 1991), p. 9.

ix Nico Wilterdink, 'The Netherlands Between the Greater Powers: Expressions of Resistance to Perceived or Feared Foreign Cultural Domination' in Rob Kroes, ed., Within the US Orbit: Small National Cultures Vis-a-Vis the United States (Amsterdam: VU University Press, 1991), p. 27.

x Wilterdink, "The Netherlands Between the Greater Powers', p. 19.

xi William Bradford, Of Plymouth Plantation, 1620-1647: The Complete Text, ed. Samuel Eliot Morison (New York: Alfred A. Knopf, 1952), p. 162.

xii Benjamin Schmidt, 'The Dutch Atlantic: From Provincialism to Globalism' in Jack P. Greene and Philip D. Morgan, eds., Atlantic History : A Critical Appraisal, (Oxford: Oxford University Press, 2008), p. 4.

xiiiCynthia van Zandt, 'Did Boundaries Really Matter in 17th Century North America?' in Elisabeth Paling Funk and Martha Dickinson Shattuck, eds., A Beautiful and Fruitful Place: Selected Rensselaerwijck Papers, vol. 2 (Albany, NY: SUNY Press, 2011), p. 175.

xiv David Savran, 'Trafficking in Transnational Brands: The New "Broadway-Style" Musical', Theatre Survey, Forthcoming, n.p.

xv Ibid.

xvi Ibid.

xvii 'Wicked - 2013 Media Night', YouTube video, 2:33, posted by 'wickedthemusicaluk', 23 Decmber 2013, http://www.youtube.com/watch?v=iS1UG8-OxL8\&feature=youtube_gdata_player, accessed 23 May 2014.

xviii Joanne Tompkins, 'Balancing the "Local" and the "Global" in Theatre for the International Stage: The Stage Adaptation of David Malouf's Johnno', in Pirkko Koski and Melissa Sihra, eds., The 
Local Meets the Global in Performance (Newcastle upon Tyne: Cambridge Scholars Press, 2010), p. 81 .

xix Dan Rebellato, Theatre and Globalization (Basingstoke: Palgrave Macmillan, 2009), p. 42, p. 44.

xx 'Some of My Favourite "Fiyero" Riffs', YouTube video, 3:05, posted by 'thewesternsky1's channel', 29 December 2011, http://www.youtube.com/watch?v=NtqqfiomvB0\&feature=youtube gdata_player, accessed 23 May 2014.

xxi Diep Tran, 'Wicked on Broadway: Talking to the 15 Wonderful Witches', Time Out, http://www.timeout.com/newyork/theater/wicked-on-broadway-talking-to-the-15-wonderful-witches, accessed 23 May 2014.

xxii Tompkins, 'Balancing the "Local" and the "Global"', p. 82.

xxiii Rebellato, Theatre and Globalization, p. 72.

xxiv Ibid.

xxv Savannah Stevenson and Willemijn Verkaik, Wicked (Apollo Victoria Theatre, London, 23 November 2013).

xxvi Wicked programme (London: The Araca Group, November 2013).

xxvii Rebellato, Theatre and Globalization, pp. 40-41.

xxviii Alberto Sandoval-Sanchez, 'Cervantes Takes Some Detours To End Up On Broadway: ReImagining Don Quijote In Man of La Mancha,' in Julio Vélez-Sáinz and Nieves Romero-Díaz, eds., Cervantes And/on/in the New World (Newark, DE: Juan de la Cuesta, 2007), pp. 195-196.

xxix Wolf, "'Defying Gravity"', p. 5.

xxx Neil Earle, The Wonderful Wizard of Oz in American Popular Culture: Uneasy in Eden (Lewiston, NY: Edwin Mellen Press, 1993), p. xiii.

xxxi These and subsequent lyrics are cited from the live performance. Wicked (Apollo Victoria Theatre, London, 23 November 2013).

xxxii William W Demastes, 'Introduction: America Defined and Refined,' in William W Demastes and Iris Smith Fischer, eds., Interrogating American Through Theatre and Performance (Basingstoke: Palgrave Macmillan, 2007), p. 3.

xxxiii Demastes, 'Introduction', p. 2.

xxxiv Victor Turner, Dramas, Fields, and Metaphors: Symbolic Action in Human Society (Ithaca: Cornell University Press, 1975), pp. 13-14.

xxxv Willemijn Verkaik, Personal interview, 29 November 2013.

xxxvi Paul R. Laird, Wicked: A Musical Biography (Lanham, MD: Scarecrow Press, 2011), p. 290. 
xxxvii Raymond Knapp, The American Musical and the Performance of Personal Identity (Princeton,

N.J: Princeton University Press, 2006), p. 264.

xxxviii Wolf, Changed for Good, p. 213.

xxxix Ibid., p. 198.

xl Jill Dolan, Utopia in Performance: Finding Hope at the Theater (Ann Arbor, MI: University of Michigan Press, 2005), p. 10.

xli Dolan, Utopia, p. 11.

xlii Wicked in Emerald, http://wickedroleplaying.weebly.com/willemijn-verkaik.html, accessed 23 May 2014.

xliii OZifizierte, 'Suche Verrückte(n) Aus Dem Raum Dortmund u.Umgebung', Wicked Die Hexen von Oz: Das Forum, 9 October 2012,

http://wickedmusical.iphpbb3.com/forum/28147311nx41867/niederlande-f73/suche-verrueckten-ausdem-raum-dortmund-uumgebung-t2014.html, accessed 23 May 2014.

xliv $\quad$ Frouke Millet De St. Aubin, 'Willemijn Verkaik Fanpage', Facebook, 15 April 2014, https://www.facebook.com/WillemijnVerkaikFanpage, accessed 23 May 2014.

xlv Rebecca Zimtkeks, 'Willemijn Verkaik Fanpage', Facebook, 1 May 2014, https://www.facebook.com/WillemijnVerkaikFanpage, accessed 23 May 2014.

xlvi Verkaik, interview, 29 November 2013.

xlvii Bernard Cova, Robert Kozinets, and Avi Shankar, Consumer Tribes (London; New York:

Butterworth-Heinemann, 2007), p. 4.

xlviii Bruce Kirle, Unfinished Show Business: Broadway Musicals as Works-in-Process (Carbondale, IL: Southern Illinois University, 2005), p. 158.

xlix $\quad$ Kirle, Unfinished, p. 11.

1 Willemijn Verkaik, 'Nothing like a Nice Warm Cup of Coffee and a Stroopwafel to "Start", I Know It's Already 4:50 Pm :), Your Day With!!,' Twitter, @WVerkaik, 11 March 2013, https://twitter.com/WVerkaik/status/311218336254009346, accessed 23 May 2014.

li Verkaik, interview, 29 November 2013.

lii Verkaik, interview, 29 November 2013.

liii Wicked (AFAS Circustheater, Scheveningen, 11 January 2013).

liv Wicked (Gershwin Theatre, New York City, 14 February 2013).

lv Wicked (Metronom Theater, Oberhausen, 20 November 2010). 
lvi 'NEW LONDON CAST FROM 18 NOVEMBER 2013', Wicked - OFFICIAL UK \& Ireland Website, http://www.wickedthemusical.co.uk/readnews.asp?id=92wkd, accessed 23 May 2014.

lvii Verkaik, interview, 29 November 2013.

lviii Verkaik, interview, 29 November 2013.

lix Verkaik, interview, 29 November 2013.

lx Lawrence Venuti, The Translator's Invisibility (London; New York: Routledge, 1995), p. 5.

1xi Verkaik, interview, 29 November 2013.

lxii Wicked (AFAS Circustheater, Scheveningen, 11 January 2013).

1xiii Dennis Kennedy, The Spectator and the Spectacle: Audiences in Modernity and Postmodernity (Cambridge: Cambridge University Press, 2011), p. 132.

lxiv Savran, 'Trafficking in Transnational Brands: The New 'Broadway-Style' Musical,' n.p. lxv Verkaik, interview, 29 November 2013. 